mierza) na rozwój polskiej pedagogiki, podobnie jak odrębnym tematem zainteresowań kolejnego badacza może być twórczość pedagogiczna lwowskich uczonych, jak również ich losy i ścieżki życiowe po zakończeniu II wojny światowej. I ta uwaga autorki, o kontynuowaniu badań nad dzjejami Kresów Wschodnich i wkładu, jaki one wniosły w historię wychowania, wydaje się być słuszna.

Edyta Glowacka-Sobiech

\title{
Krzysztof Kosiński, O nową mentalność. Życie codzienne w szko- lach 1945 - 1956, Wydawnictwo Trio, Warszawa 2000, ss. 326
}

Wydawnictwo Trio zainicjowało cykl dotyczący najnowszej historii Polski. Ową serię nazwało „W krainie PRL”. Jedną z prac jest właśnie książka Krzysztofa Kosińskiego, „O nowa mentalność. Życie codzienne w szkołach 1945-1956".

Autor chciał pokazać w swoim dziele, na tle trudnych powojennych, stalinowskich lat, obraz polskiej szkolnej rzeczywistości, uwikłanej często w polityczne zależności.

K. Kosiński podjął się zadania ukazania dziejów komunistycznych koncepcji wychowawczych i życia codziennego młodzieży z czterech powodów. Po pierwsze, chciał przyjrzeć się jdei ,walki o młodzież", która to idea była (czy też miała być) spoiwem systemu. Drugim powodem było pytanie o zachowania społeczne w wyniku oddziaływania systemu totalitarnego, liczacego na to, że uda się zmienić kaźdego człowieka na „nowego" i ,lepszego". Trzecim powodem, dla którego autor zajął się problemem, była historia zmian ludzkich zachowań - przeobrażeń społecznej mentalności, którą należy mierzyć i śledzić w kategoriach ,dlugiego trwania”. Tak długa perspektywa miała zachęcić do namysłu nad losami społeczeństwa poddanego oddziaływaniu totalitaryzmu. Czwarty powód był, wedle samego autora ,zupełnie prozaiczny", a mianowicie była nim chęć pokazania w całościowy sposób codziennego życia uczniów i presji nań wywieranych przez system komunistyczny.

Zamierzenia autora odnalazły swoje odzwierciedlenie $w$ konstrukcji pracy. Składa się ona bowiem $\mathrm{z}$ trzech części. Pierwsza $\mathrm{z}$ nich poświęcona jest samej władzy, filozofii systemu, inspiracji płynących z ZSRR, obecności partii w codziennym życiu szkoły, a także wpływowi samej władzy na szkołę i ucznia. Istotną rolę w tych procesach autor przypisal Związkowi Nauczycielstwa Polskiego. Druga część mówi o rodzicach, o tym, jaki oni wywierali wpływ na szkolę, a ona na nich. Rozdział ten z bliska także przypatruje się działalności komitetów rodzicielskich. Wreszcie trzecia, i ostatnia, część pracy poświęcona jest samej szkole. Autor pokazuje jak ona była zorganizowana, kim byli ówcześni uczniowie i nauczyciele, jak wyglądały lekcje, etykieta szkolna, rozrywka i dyscyplina, w jaki sposób karano i nagradzano uczniów, czego dotyczyły szkolne uroczystości tak państwowe, jak i jeszcze religijne, jak wpływano na mentalność i postawy prospołeczne młodzieży lat powojennych. Finalnie autor pracy analizuje także, dlaczego władza komunistyczna poniosła porażkę na polu wychowania ,nowego człowieka”, dlaczego życie społeczeństwa, a także młodzieży i nauczycieli zaczęło w 1956 roku bjec innym, niezależnym rytmem.

Baza źródłowa były dla autora w przeważajacej mierze materiały archiwalne, zdeponowane głównie w Archiwum Akt Nowych. Znaczną ich część stanowią archiwa poszczególnych szkół (szkoda, że autor zajał się, w poszukiwaniach archiwalnych, tylko szkołami średnimi, głównie liceami ogólnokształcącymi). Uzupełnieniem sa wydawnictwa dokumentów, a także prace o charakterze źródłowym, czasopisma, wspomnienia i opracowania (wybór).

W ,Podsumowaniu” autor sam przyznał, ze Polacy okazali się odporni na nowa mentalność, importowana z kraju powszechnie znienawidzonego, ,a wychowanie patriotyczne, w kiórym istotnym czynnikiem była religia, wydawało się większości nauczycielom naturalna i oczywista 
metoda pedagogiczną"1. Ponadto ideologom nie udało się skłócić pokoleń i rozbić tradyeyjnie ukształtowanego społeczeństwa, które mimo wszystko $\mathrm{z}$ jednej strony ulegało zmianom, $\mathrm{z}$ drugiej - stawało się bierne, bo ,system stawał się siła rzeczy czymś naturalnym: społeczeństwo przystosowywało się do reguł ustroju i ograniczało do sfery życia prywatnego", co było bardzo dla władzy korzystne. Trafna jest także uwaga autora, aktualna i dziś, że ,polskie społeczeństwo przestało ufać wielkim ideom. Skutkiem komunizmu
(...) okazal się relatywizm. W pewnym sensie okazał się on zgubny dla samej władzy komunistycznej, głoszacej jedyna prawde, ale stanowił chyba też poraźkę samego społeczeństwa, dla którego pragmatyzm stał się podstawową życiowa umiejętnością"2.

Edyta Gtowacka-Sobiech

I Patrz: s. 317

2 S. 320.

\section{Rola i miejsce kobiety w edukacji i kulturze polskiej, Tom 2, pod. red. Wiesława Jamrożka i Doroty Żoładź-Strzelczyk, Wydawnic- two Instytutu Historii UAM, Poznań 2001, ss. 336}

Kobieta miała zawsze do spełnienia jakâs rolę $w$ życiu. $Z$ pełnym zaangażowaniem wypełniała rolę matki, opiekunki, robotnicy czy osoby $z$ przekonaniem broniacej słusznej sprawy patriotycznej. Uwarunkowania kulturowe, historyczne często szufladkowały ja do podrzędnej roli Dzięki wytrwałej i zdecydowanej walce o honor, szacunek i podmiotowe traktowanie kobiety mogły wreszcie zaprezentować się w wielu dziedzinach życia i być aktywnymi jego uczestniczkami.

Dobrze się stało, że powyższa problematyka byla tematem konferencji i zjazdów naukowych m.in. jednej z sekcji XVI Powszechnego Zjazdu Historyków Polskich we Wroclawiu - zorganizowanego przez Polskie Towarzystwo Historyczne i Komitet Nauk Historycznych Polskiej Akademii Nauk w 1999 r. (sekcji kierowanej przez profesor Annę Żarnowską i profesor Teresę Kulak). Dobrze się również stało, że profesor Dorota Żołądź-Strzelczyk oraz profesor Wiesław Jamrożek zebrali materiały po konferencji, poświęconej problematyce kobiecej i wydali w formie ksiażkowej pt. „Rola i miejsce kobiet w edukacji i kulturze polskiej” t. II, nakładem Instytutu Historii UAM-Poznań.

Ksiażka jest zbiorem bardzo ciekawych wystapień w dyskusji w czasie konferencji naukowej
Zakładu Historii Wychowania UAM odbywajacej się 4-6 X 1999r. w Zajączkowie na temat „Działalności kobiet polskich na polu oświaty i nauki". Dzięki scalonemu opracowaniu można wysoko ocenić tę działalność. Analizując poszczególne teksty widać, że kobieta to opiekunka rannych żołnierzy, to początkowo nieśmiała guwernantka, a potem walczaca o prawa dziecka wychowawczyni i nauczycielka - również tego ubogiego i zaniedbanego dziecka wiejskiego - to osoba uczestniczaca w obronie nauki i kultury polskiej.

$\mathrm{Z}$ wyboru i często konieczności bardzo dobrze czuła się w roli właścicielki szkół, pensji zmagającej się $\mathrm{z}$ problemami ich utrzymania, troska o odpowiednia kadrę oraz wykształcenie i wychowanie powierzonych uczennic. Obwarowane niekończąca się liczba przepisów prawnych zdecydowanie pokonywały trudności w zakładaniu i prowadzeniu pensji.

Matgorzata Wrzosek w swej wypowiedzi „Właścicielki prywatnych szkół i pensji żeńskich", obok wspomnianych problemów, ilustruje czym kierowały się właścicielki przy zakładaniu tych instytucji i jakie ponosiły w zwiazku $\mathrm{z}$ tym osobiste i zawodowe koszty.

Bardzo ciekawym okazał się tekst pióra Barbary Jędrychowskiej pt. „Kobiety i zesłanki w życiu oświatowym i kulturalnym Polaków na 